\title{
College students' attitudes towards the use of Flipgrid to improve speaking skills
}

DOI: https://doi.org/10.33262/ap.v3i3.1.85

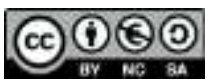

\section{Actitudes de los estudiantes universitarios hacia el uso de Flipgrid para mejorar las habilidades del habla}

Silvia Elizabeth Cárdenas Sánchez. ${ }^{1}$ \& Ximena Elizabeth Naranjo Lozada. ${ }^{2}$

\begin{abstract}
Introduction. Flipgrid, as a tool to use in class, has been designed in order to help teachers and students record videos and post them on Internet. Research has demonstrated that it works for teaching and learning English since it promotes students' interactions. Objective. This research aims to analyze students' points of view about their speaking improvement using Flipgrid. Methodology. There were 65 undergraduate students, with a A2 English level, who participated in this study and they were attending online classes because of the pandemic. Students recorded around five videos individually during the academic period and at the end of the semester they answered a questionnaire and had an interview with the instructor. The interviews were necessary in order to know opinions and attitudes about the use of Flipgrid as an innovative form of instruction of English as a Foreign Language. Results. The results demonstrated that students liked to use Flipgrid and their confidence, motivation, vocabulary, language and pronunciation improved. Conclusion. The use of Flipgrid as an online resource can be beneficial for students in order to promote speaking skills; however, there are some important implications that language instructors need to consider during the language learning process if they decide to use Flipgrid in classes.
\end{abstract}

\footnotetext{
1 Escuela Superior Politécnica de Chimborazo, Sede Morona Santiago, Morona Santiago, Ecuador, silvia.cardenas@espoch.edu.ec, https://orcid.org/0000-0002-1760-8288

2 Universidad Técnica de Ambato, Centro de Idioma. Ambato-Tungurahua, Ecuador. xe.naranjo@uta.edu.ec, https://orcid.org/0000-0002-7077-4269
} 
Key words: Flipgrid, Interaction, Motivation, Speaking skills.

\section{Resumen}

Introducción. Flipgrid, como herramienta para usar en clase, ha sido diseñado para ayudar a profesores y estudiantes a grabar videos y publicarlos en Internet. La investigación ha demostrado que funciona para la enseñanza y el aprendizaje del inglés, ya que promueve la interacción de los estudiantes. Objetivo. Esta investigación tiene como objetivo analizar los puntos de vista de los estudiantes sobre su mejora en el habla utilizando Flipgrid. Metodología. Fueron 65 estudiantes de pregrado, con un nivel de inglés A2, que participaron de este estudio y estaban asistiendo a clases en línea debido a la pandemia. Los estudiantes grabaron alrededor de cinco videos de forma individual durante el período académico y al final del semestre respondieron un cuestionario y tuvieron una entrevista con el instructor. Las entrevistas fueron necesarias para conocer opiniones y actitudes sobre el uso de Flipgrid como una forma innovadora de instrucción del inglés como lengua extranjera. Resultados. Los resultados demostraron que a los estudiantes les gustaba usar Flipgrid y mejoraron su confianza, motivación, vocabulario, lenguaje y pronunciación. Conclusión. El uso de Flipgrid como recurso en línea puede ser beneficioso para los estudiantes con el fin de promover las habilidades para hablar; sin embargo, existen algunas implicaciones importantes que los profesores de idiomas deben tener en cuenta durante el proceso de aprendizaje del idioma si deciden utilizar Flipgrid en las clases.

Palabras clave: Flipgrid, Interacción, Motivación, Habilidades de expresión oral.

\section{Introduction}

Learning English involves the development of different skills that are going to help learners improve knowledge and use it in a real context. Learning a language means more than grammar knowledge. Students from different levels need to keep practicing language skills in different contexts and using different strategies. One of the skills is speaking, which helps students to communicate their ideas and thoughts to others. According to Rao (2019), speaking skills is a productive skill and it is important because people need to communicate in real life situations in this modern world where communicating skills have become a crucial element to look for a job. In other words, developing speaking skills in language learning must be a main activity for educators and students because it is the language production. Moreover, it is necessary to state that the teachers can use teaching strategies; but students need to develop their learning strategies according to their preferences.

Speaking skill can be mastered using different strategies and resources. Gani, Fajrina and Hanifa (2015) conducted a study in order to understand students' learning strategies to enhance their speaking skills and the results demonstrated that students with a high English level used more learning strategies than those who were at a low level. High level 
english students relied more on listening songs, watching movies, reading english books and articles, talking to friends and other activities like repeating words and talking to themselves. All those learning strategies are part of the cognitive and metacognitive activities that a student can perform inside or outside the class.

Today, teachers and students can find plenty of materials and useful applications that will support the teaching and learning process. Bahadorfar and Omidvar (2014) mention that technology is one of the best resources, which can lead knowledge in this, globalized worlds. The authors conclude, "Internet, podcasts, video conferencing, videos and speech recognition software are considered the best tools for teaching speaking skill." (p. 9). Consequently, teachers have to look for resources available on internet and try to incorporate in their classes. These resources that must be innovative and convenient in the $21^{\text {st }}$ century. It is also known that innovation in a class takes place when educators apply different strategies using technological tools that are convenient for students learning process. According to Linney (2020), innovating in teaching is essential if an institution wants to evolve. Hence, the author mentions that culture, creativity and technological advancement are the critical areas where administrators and teachers have to focus on in higher education mainly. Furthermore, Lynch (2018) mentions that innovative classes are beneficial for students because they are engaged and improve their learning. It means that an innovative class helps students to reflect, learn constantly, create, find solutions, collaborate and establish connections or routines.

Kasapoğlu-Akyol (2010) conducted a study with ESL students to find out how they use technology in order to improve their English knowledge and the results demonstrated that students certainly look for many technological tools to improve skills like listening and speaking. One of the tools that students found useful was recording themselves and they mentioned this strategy helped them improve pronunciation and speaking skills. Green and Green (2018) state that Flipgrid allow students to record voice or video in order to create discussion topics with teachers' guide and engage students in remote learning. There are many options in Flipgrid for free enough to use as a source in different learning settings like online and face to face. However, users can pay in order to customize their tasks and allow students to have a better experience if they use this tool. In other words, this application is a tool, which allows users to create videos by recording themselves and sharing with others their responses. Additionally, this tool permits teachers to create discussions because a teacher can post a topic and students respond about it by recording their answers or they can share the link to others. This application has been beneficial in remote learning since students do not need any special accommodations in order to record the videos. (Edwards, 2021).

Flipgrid is an application that can support teachers' class delivery because it has been proved that it works in different settings. According to Budiarta and Santosa (2020), digital literacy is important in this century and technology should be integrated in the pedagogical practices even more when teaching or learning English. Therefore, these researchers integrated a strategy called Think Pair Share (TPS) finding a support with Flipgrid. This teaching model helped in their speaking class in order to develop TPS and 
promote speaking skills. The results demonstrated that using Flipgrid encouraged students to improve their speaking performance, fluency and comprehension. Furthermore, the study confirmed that students were involved and motivated in the speaking tasks, and it demonstrates that the use of Flipgrid can bring excellent results if teachers use in their settings.

In addition, Flipgrid has widely used in online classes as an innovative form of providing students opportunities to give opinions and practice speaking skills. For instance, Lowenthal and Moore (2020) in their study where Flipgrid was used in asynchronous video-based activities, students reported that Flipgrid was easy to use and they enjoyed using this application. Furthermore, Keiper, White, Carlson and Lupinek (2021) state that Flipgrid is favorable if it is used as a learning tool with an hybrid flexible method in higher education since the results of the study concluded that course delivery must be focused on interaction and this tool is appropriate to promote it.

\section{Methodology}

The purpose of this study was to understand students' perceptions about the efficacy of Flipgrid in language production. Participants recorded their responses based on each class topic, which required students' opinions or language practice. Each student recorded five videos during the semester. The videos length was no more than 2 minutes and the topics were focused on language use within authentic situations.

In addition, this research was conducted in a setting where English is taught as a foreign language. Students from level A2 participated in the study. It is important to mention that this study was carried out when students started to take online classes due to the pandemic situation. The participants were undergraduate students who were enrolled in online English classes during a 4-month academic period from May to August in 2020. Students were majoring in different fields, but the English curriculum was the same since the university promotes the learning of general English. 65 out of 72 college students participated in this study. The demographic data collected in the study only consisted on genre and there were 37 men and 28 women.

This research is mixed method because data were collected and analyzed from a questioner with likert scale questions, dichotomous questions, and open-ended questions. Additionally, there were students' interviews, which took placed at the end of the study similarly. The quantitative questions were applied in order to understand students' motivation, language and vocabulary development according to students' beliefs. On the other hand, there was a question, which lead to understand the number of repetitions that students needed to get the final product and how these repetitions influenced in their language practice. The open-ended questions and interviews helped to collect students' attitudes towards the use of Flipgrid to elaborate videos using the English language. 


\section{Results}

The information was collected using Google forms. The survey was sent to 72 students, but 65 submitted their answers. In other words, the students' response rate was $90 \%$. The survey contained items, which aimed to look for information about students' perceptions on their improvement on motivation, fluency, vocabulary knowledge, confidence, language and pronunciation. Furthermore, one question was integrated in order to know the number of repetitions each student had to do in order to get the final product. In terms of students' perceptions about the usefulness of Flipgrid, an open-ended question helped to collect students' opinions. Finally, students' interviews were also analyzed and the ideas were captured in quotes.

The results demonstrated that students recommend the use of Flipgrid in general to produce speaking skills while learning the English language. However, it is important comprehend other aspects about language development and how the tool Flipgrid was used in order to achieve language learning objectives. To start with motivation, $78.5 \%$ of students concluded that using Flipgrid helped them increase their motivation to learn the language. Secondly, students reported that their language fluency increased a lot with a $53.8 \%$ and $41.5 \%$ considered that their fluency increased in a low extent. Thirdly, students' pronunciation has also increased to a high extent in around $56.9 \%$ and to a low extent in $41.5 \%$. The average response about students' confidence on a scale 1-3 was 1.5 where $58.5 \%$ reported that their confidence increased a lot, while $38.5 \%$ concluded that it increased in little form. Surprisingly, $64.6 \%$ students mentioned that their vocabulary increased. Then $35.4 \%$ manifested that their vocabulary increased a little bit. Lastly, $55.4 \%$ students mentioned that their language use increased in a high extent and $44.6 \%$ of students thought that it improved in a little way (see table 1).

Table 1

Students' perception about the use of Flipgrid

Nothing A little A lot $\begin{gathered}\text { Total } \\ \%\end{gathered}$ Total Mean $\begin{gathered}\text { Std. } \\ \text { Deviation }\end{gathered}$

\begin{tabular}{lccccccc}
\hline $\begin{array}{l}\text { Increased } \\
\text { students' } \\
\text { motivation }\end{array}$ & $1.5 \%$ & $20 \%$ & $51 \%$ & 100 & $\mathrm{~N}=65$ & 1.23 & .46 \\
$\begin{array}{l}\text { Increased } \\
\text { students' language } \\
\text { fluency }\end{array}$ & $4.6 \%$ & $41.5 \%$ & $53.8 \%$ & 100 & $\mathrm{~N}=65$ & 1.51 & .59 \\
$\begin{array}{l}\text { Students' } \\
\text { improved } \\
\text { pronunciation }\end{array}$ & $1.5 \%$ & $41.5 \%$ & $56.9 \%$ & 100 & $\mathrm{~N}=65$ & 1.45 & .53 \\
& & & & & & &
\end{tabular}


Table 1

Students' perception about the use of Flipgrid (continuación)

\begin{tabular}{lccccccc}
\hline & Nothing & A little & A lot & $\begin{array}{c}\text { Total } \\
\%\end{array}$ & Total & Mean & $\begin{array}{c}\text { Std. } \\
\text { Deviation }\end{array}$ \\
\hline $\begin{array}{l}\text { Increased } \\
\text { students' } \\
\text { confidence }\end{array}$ & $3.1 \%$ & $38.5 \%$ & $58.5 \%$ & 100 & $\mathrm{~N}=65$ & 1.45 & .56 \\
$\begin{array}{l}\text { Increased } \\
\text { vocabulary } \\
\text { knowledge }\end{array}$ & $0 \%$ & $35.4 \%$ & $64.6 \%$ & 100 & $\mathrm{~N}=65$ & 1.35 & .48 \\
$\begin{array}{l}\text { Increased } \\
\text { language use }\end{array}$ & $0 \%$ & $44.6 \%$ & $55.4 \%$ & 100 & $\mathrm{~N}=65$ & 1.45 & .50 \\
\hline
\end{tabular}

Note: Students' points of view about the use of Flipgrid and its implications in their English language improvement.

In addition, this study also aimed to know students issues related with recording a video and their opinion about doing this kind of activity with Flipgrid. According to the data, $36.9 \%$ of students repeated the video more than 5 times and probably it took some time to complete the task. On the other hand, $58.4 \%$ of students answered that they had to repeat between 2 and 5 times in order to get the final product. Only $4.6 \%$ of students mentioned they completed their task with one attempt and they did not need to repeat the task (see Figure 1).

Figure 1

\section{Number of repetitions to get the final product}

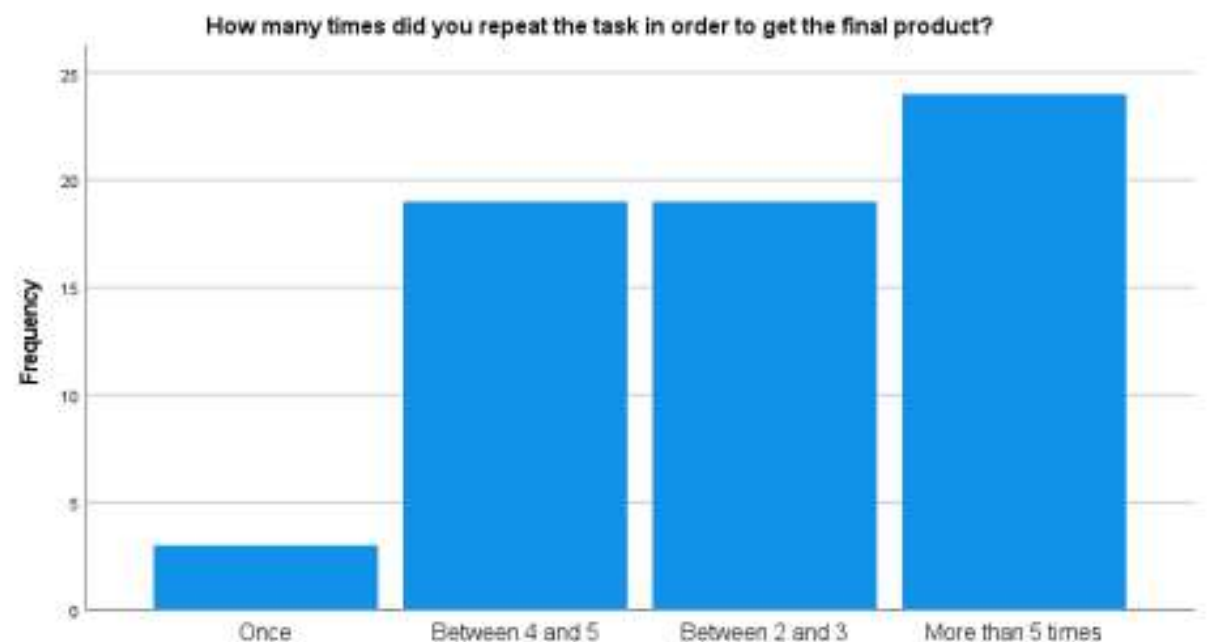

Note: Students' number of repetitions in order to get the final video recording.

Resource: Authors' elaboration 
Despite the fact that students needed to repeat the recording until they got the final product, they concluded that it helped to practice more the language. In general, $69.2 \%$ of students suggest the use of Flipgrid as a technological tool to record videos and they recommend the use of it in class instruction.

Based on students' interviews, there were some insightful opinions from students, which helped to understand the importance of practicing speaking with different topics, and some opinions are quoted in the following list:

S1: This tool helped me complete the task in an easy way and I could practice more English. I liked it and I want to keep using in the future.

S2: I suggest teachers to do activities like this and use Flipgrid to help us to develop our English knowledge because it is necessary to learn English in order to get scholarships.

S3: I consider Flipgrid encouraged me to record many times until I got a good recording and I got a good grade. I really felt motivated with this kind of task.

On the other hand, students also mentioned their point of view about the convenience of Flipgrid in order to complete the assignments. Students' opinions were:

S4: I would choose Flipgrid because it is a tool easy to use and it allows us to do our task in a simple and clear form.

S5: I did not like Flipgrid because in my opinion, it is not private and you can post your videos and other people could see it. I do not feel comfortable when others watch something I have recorded as a task.

S6: I would use it in the future because I could see my teacher and partners recordings, so it helped me with my recording because I had a clear idea of what to do.

The data collected from interviews and open-ended questions indicates students' perspectives towards the use of Flipgrid as positive because they could practice language, it was a different way to hand in tasks, and easy to use.

\section{Conclusions}

- Flipgrid has been increasing its use in classes in order to promote interaction. Flipgrid allows students and teachers to record responses to prompts and they appear on videos. Largely, this study lead to understand that Flipgrid, as a tool, is suitable to use in an English class. Students' opinions demonstrated that Flipgrid was easy to use and they could hand in their task without problems in most of the cases. Moreover, this technological tool involved students in the task and the practice where carried out with topics from real contexts. Students' attitudes towards the use of Flipgrid during the class were positive and some of their 
answers provide a guide in order to keep working with video recordings while learning a language.

- Researchers need to take into account some limitations in this study since the methodology used in it was limited to record a response and it did not required students' opinions about their partners' recordings. Therefore, it is necessary that new studies be focused on language interaction through the use of Flipgrid by adding students' comments on others' responses. Another point worth noting is the fact that the sample size was limited to one higher education institution. Hence, future studies should aim to reach more public and private universities across the country.

\section{References}

Budiarta, I. K., \& Santosa, M. H. (2020). TPS-Flipgrid: Transforming EFL speaking class in the 21st century. English Review: Journal of English Education, 9(1), 13-20.

Bahadorfar, M., \& Omidvar, R. (2014). Technology in teaching speaking skill. Acme International Journal of Multidisciplinary Research, 2(4), 9-13.

Edwards, L. (2021). What is Flipgrid and how does it work for teachers and students? TechLearningMagazine. https://www.techlearning.com/how-to/what-is-flipgridand-how-does-it-work-for-teachers-and-students

Gani, S. A., Fajrina, D., \& Hanifa, R. (2015). Students' learning strategies for developing speaking ability. Studies in English Language and Education, 2(1), 16-28.

Green, T., \& Green, J. (2018). Flipgrid: Adding voice and video to online discussions. TechTrends, 62(1), 128-130.

Kasapoğlu-Akyol, P. (2010). Using educational technology tools to improve language and communication skills of ESL students. Novitas-Royal, 4(2).

Keiper, M. C., White, A., Carlson, C. D., \& Lupinek, J. M. (2021). Student perceptions on the benefits of Flipgrid in a HyFlex learning environment. Journal of education for business, 96(6), 343-351.

Linney, S. (2020). How to encourage innovation in teaching for World-Class learning. QS. https://www.qs.com/how-to-encourage-innovation-in-teaching-for-worldclass-learning/

Lowenthal, P. R., \& Moore, R. L. (2020). Exploring Student Perceptions of Flipgrid in Online Courses. Online Learning, 24(4), 28-41.

Lynch, M. (2018). 10 characteristics of an innovative classroom. Education Week. https://www.edweek.org/education/opinion-10-characteristics-of-an-innovativeclassroom/2018/07 
Rao, P. S. (2019). The importance of speaking skills in English classrooms. Alford Council of International English \& Literature Journal (ACIELJ), 2(2), 6-18. 


\section{PARA CITAR EL ARTÍCULO INDEXADO.}

Cárdenas Sánchez, S. E., \& Naranjo Lozada, X. E. (2021). College students' attitudes towards the use of Flipgrid to improve speaking skills . AlfaPublicaciones, 3(3.1), 175184. https://doi.org/10.33262/ap.v3i3.1.85

\section{LCiencia}

El artículo que se publica es de exclusiva responsabilidad de los autores y no necesariamente reflejan el pensamiento de la Revista Alfa Publicaciones.

El artículo queda en propiedad de la revista y, por tanto, su publicación parcial y/o total en otro medio tiene que ser autorizado por el director de la Revista Alfa Publicaciones.
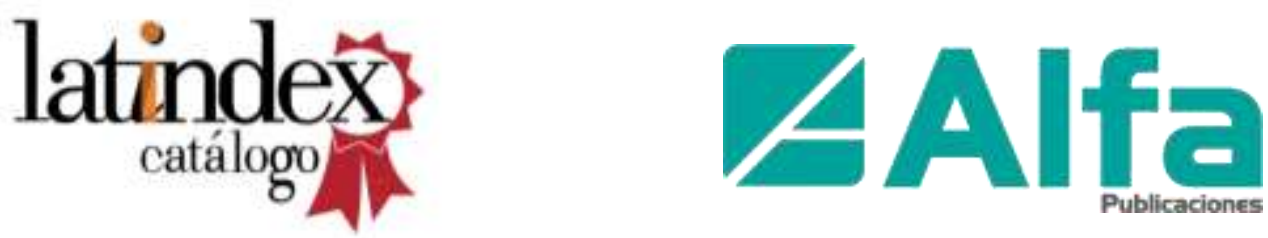